\title{
Pengembangan Media Pembelajaran Boneka Tangan Mata Pelajaran Bahasa Indonesia Materi Menyimak Dongeng pada Siswa Kelas II Sekolah Dasar
}

\author{
Rosaria Yulinda Krisanti $^{1 *}$, Suprihatien ${ }^{2}$, Diah Yovita Suryarini ${ }^{3}$ \\ 1,2,3Pendidikan Guru Sekolah Dasar, Fakultas Bahasa dan Sains \\ Universitas Wijaya Kusuma Surabaya \\ Email:* rosariayulindakrisanti82@gmail.com
}

\begin{abstract}
The lack of teaching effectiveness in teaching learning activity made students felt bored easily and noisy in the classroom. To resolve that problem needed teaching media used in learning process, one of them was puppet that developed as learning media completed with the stage to show the location of the story. This medium was used for understanding fairy tale material to intermediate grade 2. This writing used the development of Addie model (analysis, design, development, implementation, and evaluation). According to this unable condition to do a research, so this research ended in validity step as a measurement of worthiness using puppet medium for understanding fairy tale material. The worthiness of the validity media result was $94 \%$, whereas validity material result in the first validator was $88,3 \%$ and the second was $86,6 \%$. According to that validity result, we could conclude that teaching media using puppet could be used for understanding fairy tail material for intermediate grade 2 .
\end{abstract}

Keywords: media development of hand puppets, Indonesian language learning, listening to fairy tales.

\begin{abstract}
Abstrak
Kurangnya efektivitas belajar pada kegiatan belajar mengajar membuat murid cepat bosan dan gaduh didalam kelas. Untuk mengatasi hal tersebut diperlukan media pembelajaran dalam proses berlangsungnya belajar mengajar, salah satunya yaitu pengembangan media belajar boneka tangan dengan kelengkapan panggung boneka sebagai penunjuk latar tempat. Penerapan media belajar boneka tangan dapat digunakan pada materi dalam menyimak/ mendengarkan dongeng pada siswa kelas II Sekolah Dasar. Penulisan ini menerapkan model pengembangan ADDIE (analysis, design, development, implementation, and evaluation). Melihat keadaan yang tidak memungkinkan untuk melaksanakan penelitian maka penulisan ini hanya sampai tahap validasi saja sebagai tolak ukur kelayakan media boneka tangan pada materi menyimak/ mendengarkan dongeng. Kelayakan dari hasil validasi media sebesar 94\%, sedangkan hasil validasi materi pada validator pertama sebesar $88,3 \%$ dan validator kedua sebesar $86,6 \%$. Selanjutnya dapat disimpulkan bahwasanya media pembelajaran boneka tangan dapat digunakan untuk materi menyimak/ mendengarkan dongeng pada siswa kelas II Sekolah Dasar.
\end{abstract}

Kata kunci: pengembangan media boneka tangan, pembelajaran bahasa Indonesia, materi menyimak dongeng. 


\section{PENDAHULUAN}

Permasalahan yang terjadi dalam dunia pendidikan yaitu lemahnya penerapan guru dalam melaksanakan proses belajar mengajar (Susanto, 2013:165). Kemampuan berfikir setiap anak selalu berbeda-beda ada anak yang memunyai kemampuan berfikir tinggi, sedang dan rendah. Kemampuan berfikir tersebut dapat dilihat karena gaya belajar siswa yang berbeda, lingkungan serta latar belakang siswa. Di sekolah anak dituntut untuk menerima informasi pembelajaran yang sama dengan teman lainnya, agar tujan pembelajaran dapat tercapai dengan sempurna. Hal tersebut terjadi pada saat observasi langsung dalam melaksanakan PPL, dalam proses pembelajaran siswa hanya diarahkan pada kemampuan menghafal dan memahami isi materi pembelajaran yang ada pada buku ajar. Proses pembelajaran tersebut terlihat sangat membosankan, serta membuat siswa gaduh didalam kelas.

Dilihat dari permasalahan yang dialami oleh penulis dapat dikatakan bahwa media pembelajaran sangat penting digunakan untuk menyampaikan suatu informasi pembelajaran kepada siswa, sehingga siswa yang memunyai kemampuan berfikir tinggi, sedang dan rendah dapat berjalan seimbang sesuai dengan tujuan pembelajaran yang diinginkan sekolah. Tentunya dalam penggunaan media pembelajaran disesuaikan dengan perkembangan zaman. Namun tidak semua sekolah mempunyai sarana yang lengkap untuk menyampaikan informasi pembelajaran pada siswa, sehingga dengan keterbatasan sarana yang ada guru harus bisa menyampaikan informasi setidaknya menggunakan media pembelajaran yang efisien walaupun sederhana dan murah, namun tujuan pembelajaran dapat tercapai. Seorang guru juga dituntut untuk memunyai pengetahuan dan pemahaman yang cukup tentang media pembelajaran yang terkait dengan pengembangan. Guru merupakan salah satu faktor penentu keberhasilan suatu pembelajaran, salah satunya mata pelajaran bahasa Indonesia materi menyimak dongeng. Siswa harus mampu mendengarkan dan memahami materi yang diberikan oleh guru, karena tujuan kemampuan menyimak adalah agar siswa dapat memahami sebuah informasi yang didapatkan. Tentunya dengan mengetahui tujuan pembelajaran tersebut perlu adanya media yang dapat memperjelas isi suatu dongeng yang diberikan oleh guru kepada siswa, sehingga dapat menggunakan mainan boneka tangan yang dikembangkan menjadi media pembelajaran menyimak dongeng.

Pemilihan media pembelajaran boneka tangan ini berdasarkan pengalaman penulis saat melaksanakan PPL bahwa, guru hanya menggunakan media 
pembelajaran yang ada yaitu buku LKS, teks cerita, papan tulis, dan gambar-gambar yang ditempel di depan kelas yang membuat siswa cepat bosan dan gaduh didalam kelas. Menurut Umam, dkk (2019:3) Dengan penggunaan penggunaan buku standart umum dan belum dimanifestasikan sesuai dengan materi dapat mengurangi pemahaman siswa terhadap isi materi yang disampaikan oleh guru. Maka untuk mengatasi permasalahan tersebut perlu adanya tambahan media pembelajaran boneka tangan yang diharapkan dapat mengembangkan aktivitas belajar siswa dan antusias siswa terhadap pelajaran bahasa Indonesia materi menyimak khususnya pada siswa kelas II. Penggunaan boneka tangan ini disesuaikan dengan dongeng yang akan disampaikan dan dilengkapi dengan pangung untuk memperlihatkan latar tempat yang akan di tampilkan. Media pembelajaran boneka tangan ini sangatlah cocok digunakan pada siswa kelas rendah, karena siswa kelas rendah masih mempunyai daya imajinasi yang tinggi dan memiliki antusias dalam belajar jika mereka menggunakan media nyata atau media tiga dimensi dan dapat didemonstrasikan di depan kelas.

Kegiatan pengembangan dilaksanakan dengan tujuan: 1) Menghasilkan media pembelajaran boneka tangan yang laayak, diterapkan pada mata pelajaran menyimak dongeng kelas II
Sekolah Dasar, 2) Mengetahui media pembelajaran boneka tangan dalam proses pembelajaran berdasarkan hasil dari validasi ahli materi dan validasi ahli media.

Berdasarkan efektivitas pemanfaatan media pembelajaran dan melihat keadaan yang tidak memungkinkan untuk melaksanakan penelitian karena adanya wabah COVID-19, maka penulis membatasi penelitian yang dilaksanakan, yaitu hanya penyusunan perangkat pembelajaran saja.

\section{Media Pembelajaran}

Pengertian media dalam

kegiatan pembelajaran lebih dimaknai menjadi alat photografis atau elektronis dalam menangkap, mengoperasikan, serta mengatur ulang informasi visual/ verbal (Arsyad, 2013:3). Selanjutnya Danim (2008:7) media pendidikan diartikan sebagai perangkat seorang pendidik dalam membangun komunikasi dengan siswanya. Pendapat Jalinus dan Ambiyar (2016:4) menyatakan media pembelajaran merupakan segala sesuatu mengenai perangkat lunak dan perangkat keras dapat diterapkan dalam memberikan materi dari sumber pembelajaran kepada siswa baik secara mandiri ataupun kelompok maka, dalam pembelajaran berlangsung dapat meningkatkan perhatian siswa dan minat belajar siswa sehingga kegiatan pembelajaran tersebut menjadi lebih efektif. 
Dari beberapa paparan di atas dapat disimpulkan bahwa media pembelajaran adalah sarana yang dapat menyalurkan informasi mengenai pembelajaran dari seorang guru kepada siswanya, sehingga dapat merangsang rasa ingin tahu siswa lebih tinggi, maka tujuan pembelajaran dapat tercapai dengan baik.

Macam-macam

Pembelajaran

$\begin{array}{lrr}\text { Seorang } & \text { guru } & \text { tentunya } \\ \text { memerlukan } & \text { suatu } & \text { media }\end{array}$ pembelajaran untuk menyampaikan informasi pembelajaran supaya informasi yang diberikan diterima dengan baik, selain itu dapat merangsang rasa ingin tahu siswa lebih baik. Menurut Desiningrum, dkk (2017: 137) macam-macam media pembelajaran dapat dikelompokkan menjadi 4 antara lain:

a. Media audio

Media audio merupakan bentuk alat peraga yang dipakai dalam kegiatan belajar mengajar yang mengeluarkan suara saja, sehingga hanya menggunakan alat indera pendengar.

b. Media visual

Media visual merupakan bentuk alat peraga yang berupa gambar atau lukisan dan hanya bisa dilihat menggunakan alat indera penglihatan.

c. Media audio-visual

Media audio-visual merupakan jenis media berupa gambar yang dapat bergerak dan mengeluarkan suara, sehingga menggunakan indera penglihatan dan indera pendengar media tersebut adalah vidio.

d. Multimedia

Multimedia merupakan sarana yang menyangkut semua indera pada satu kegiatan belajar.

Berdasarkan penjelasan diatas, penulis menyimpulkan bahwa bentuk media dapat dijabarkan menjadi empat jenis yaitu media audio, media visual, media audio-visual, dan media multimedia . Pada penelitian kali ini peneliti menggunakan sebuah media visual 3D berupa boneka tangan, karena boneka tangan hanya dapat dilihat dari berbagai arah, namun tidak menghasilkan suara, serta dalam klasifikasinya boneka tangan termasuk dalam media tiga dimensi .

\section{Boneka Tangan sebagai Media Pembelajaran Bahasa Indonesia}

Berdasarkan permasalahan yang ditemui penulis, sering kali pada pembelajaran bahasa Indonesia guru jarang atau bahkan tidak menggunakan media untuk menyampaikan suatu informasi terutama pada materi menyimak dongeng, maka penulis menggunakan media pembelajaran boneka tangan untuk menarik perhatian dan antusias belajar siswa .

Metode bercerita dengan berbantuan media boneka tangan adalah cara yang tepat pada proses 


\section{Krisanti, dkk}

belajar, karena dengan bantuan media siswa bisa mengembangkan kemampuan imajinasinya, kemampuan menerima pelajaran dengan baik, mengajarkan anak untuk bersimpati dan berempati, membantu siswa memberikan contoh dalam menanggapi suatu kejadian atau memecahkan permasalahan berdasar pada pengalaman dan menarik pesan yang terdapat pada sebuah cerita (Chrisyarani, 2018 : 59).

Menurut Widowati (2016:2.583) boneka merupakan benda yang disenangi oleh anakanak, maka pemilihan boneka tangan sangatlah cocok karena dapat menarik perhatian siswa. Adapun Andriani (2017:4) berpendapat bahwa dengan penerapan media boneka tangan guru dengan mudah membantu siswa dalam memperlihatkan hal abstrak, pengasahan rasa, rangsangan pada kreativitas, menemukan pandangan, serta menjelaskan konsep/ rancangan supaya membangkitkan kesenangan siswa dalam pembelajaran menyimak/ mendengarkan.

Dari beberapa paparan di atas dapat disimpulkan bahwa boneka tangan dapat digunakan sebagai sarana pembelajaran pada anak-anak, karena yang dapat menyerap pembelajaran lebih tinggi yang disampaikan oleh guru dan dapat memvisualkan hal-hal abstrak serta menggantikan objek nyata.

\section{Pengertian Menyimak dalam Bahasa Indonesia}

Siswa harus memiliki keterampilan dari Sekolah Dasar yaitu keterampilan bahasa yang baik. Dalam bahasa Indonesia, diharuskan siswa memiliki empat ada empat keterampilan berbahasa yakni: mendengarkan; berbicara; membaca; dan menulis. Keterampilan berbahasa tersebut saling berkaitan antara satu dengan lainnya (Susanto, 2013:241). Setiap siswa mempunyai daya pikir yang berbeda, salah satunya keterampilan menyimak. Pendapat tersebut didukung oleh Nopriani, dkk (2016:122) menyimak merupakan suatu kegiatan mendengarkan dengan cara menyimak, sehingga anak mengetahui memahami pesan dan informasi yang telah diberikan. Selain itu, menyimak juga diartikan sebagai keterlibatan dalam kegiatan mendengarkan dan melihat informasi yang didapat sehingga hasilnya akan semakin baik juga.

Menurut Omih (2017:63) menyimak merupakan proses keterampilan yang mencangkup kegiatan mendengarkan, identifikasi, mengapresiasi, menginterprestasi untuk mendapatkan informasi dan memahami arti dari komunikasi yang disampaikan secara lisan.

Dari beberapa pengertian di atas dapat disimpulkan bahwa menyimak adalah suatu proses ketrampilan yang melibatkan keterampilan mendengarkan, guna mendapatkan informasi yang 
disampaikan kepada pendengar secara lisan.

\section{Definisi Dongeng}

Dongeng merupakan cerita fiktif yang digunakan dalam menghibur dan menyampaikan nilai budi pekerti dari cerita tersebut (Habsari, 2017:23), sedangkan menurut Trianto (2007:46) dongeng merupakan cerita sederhana yang tidak benar terjadi atau peristiwa yang tidak biasa terjadi. Dongeng mempunyai kegunaan untuk memberikan didikan moral dan bersifat menghibur serta termasuk dalam cerita tradisional.

Dari pendapat diatas disimpulkan bahwasanya dongeng adalah cerita fiktif yang mengandung nilai moral dan menghibur. Cerita tersebut merupakan dasar dari imajinasi seorang anak.

\section{Jenis-jenis Dongeng}

Dongeng memunyai banyak jenis yang dapat diceritakan kepada anak-anak, jenis-jenis dongeng tersebut dapat menarik perhatian dan mengembangkan imajinasi seorang anak. Menurut Habsari (2017:23) jenis-jenis dongeng dapat dibagi menjadi tujuh, yaitu: 1) mitos, adalah jenis dongeng yang menggambarkan hal-hal magis seperti cerita tentang dewa-dewa, peri atau Tuhan; 2) sage, adalah bentuk dongeng yang menceritakan kepahlawanan, keberanian, atau sihir; 3) fable, adalah bentuk dongeng yang menceritakan hewan yang bisa berbicara atau berperilaku layaknya manusia; 4) legenda, adalah bentuk dongeng yang menceritakan suatu peristiwa tentang asal mula suatu benda atau tempat; 5) cerita jenaka, adalah cerita yang berkembang di masyarakat dan bisa menghibur; 6) cerita pelipur lara, berbentuk diskripsi yang bertujuan untuk menghibur tamu di pesta dan kisah yang diceritakan oleh seorang ahli; 7)cerita perumpamaan, adalah bentuk dongeng yang mengandung makna.

\section{Unsur-unsur Dongeng}

Agar dongeng menjadi sempurna dan diminati banyak pembaca pastinya dalam penyusunannya memiliki unsur didalamnya. Menurut Trianto (2007:46) Unsur pembangun dari dongeng ada enam yaitu :

a. Tema

Tema yaitu pokok pemikiran yang digunakan sebagai dasar pengarang, pokok pemikiran pengarang, dan ide pokok masalah. Di dalam dongeng biasanya diuraikan beberapa hal, seperti: 1) moral tentang kejadian kemenangan melawan kejahatan; 2) kejadian dimasa lalu, tempatnya sangat jauh sekali; 3) tidak ada kemungkinan tugas dilakukan; 4) mantra ajaib, misal dapat mengubah manusia menjadi hewan; 5) munculnya daya tarik dari kebaikan maupun kasih sayang; 6) pemberian pertolongan pada orang baik, dan lain sebagainya. b. Penokohan

Penokohan dapat menunjukkan tokoh dan perwatakan 
sang tokoh. Tokoh merupakan pelaku atau pemeran sebuah cerita melalui watak berbagai aksi yang dilakukannya. Pelaku yang biasa diperankan di dalam dongeng seperti: a) dewa dan dewi, ibu dan saudara tiri yang jahat, raja dan ratu, pangeran dan putri; b) peri, wanita penyihir, raksasa, orang kerdil, putri duyung, monster, naga; c) binatang, misalnya: keong emas, ikan ajaib dan kancil; d) kastil, hantu yang memikat, kerajaan, dan negeri ajaib; e) benda ajaib, misal lampu ajaib, cincin, permadani, dan cermin.

a. Latar

Latar adalah keterangan dari suasana kejadian peristiwa pada tempat serta waktu. Latar memberikan cerita secara konkret dan jelas. Untuk penentuan latar sangat penting untuk memberikan kesan realistis dan jelas. Dalam latar cerita ini dibagi menjadi tiga, yaitu:

1) Latar tempat, tempat kejadian peristiwa; 2) Latar waktu, masa waktu tertentu ketika terjadinya peristiwa dalam cerita; 3) Latar suasana, gambaran keadaan peristiwa dalam sebuah cerita.

b. Sudut Pandang

Merupakan kedudukan/ posisi pengarang dalam cerita, cara pandang pengarang. Sudut pandang setiap pengarang dalam cerita sangatlah berbeda. Pengarang dapat memakai sudut pandang orang pertama (aku, saya). Sudut pandang orang kedua (kamu, kau). Dan terakhir dapat menggunakan sudut pandang orang ketiga (ia, dia, atau nama orang). c. Amanat
$\quad$ Adalah
$\begin{aligned} & \text { pesan } \\ & \text { disampaikan } \\ & \text { sebuah cerita. }\end{aligned}$

Berdasarkan uraian di atas adanya karakteristik dongeng yang membantu mengembangkan imajinasi siswa dalam memahami isi dongeng, maka peneliti mengembangkan media boneka tangan menjadi media pembelajaran yang sesuai.

\section{METODOLOGI PENGEMBANGAN}

$$
\text { Pada }
$$

penelitian

pengembangan

media

pembelajaran boneka tanganpenulis mengacu pada pengembangan $\mathrm{AD}$

DIE (analysis, design, development, implementation, and evaluation). Menurut Cahyadi (2019:35) model ADDIE adalah suatu model desain pembelajaran yang menunjukkan langkah-langkah dasar pada sistem pembelajaran dalam penerapannya sangatlah mudah dilakukan. Model ini dibuat secara tersusun dengan terstrukturnya urutan kegiatan dalam usaha memecahan masalah belajar dalam kaitannya dengan sumber belajar yang sesuai dengan kebutuhan serta karakteristik pembelajaran Tegeh dan Kirna (2013:16). Tahapan model ADDIE dapat dilihat pada gambar 1. Namun karena kondisi yang tidak memungkinkan untuk melaksanakan penelitian, maka penelitian kali ini akan berhenti pada proses validasi ahli saja. 


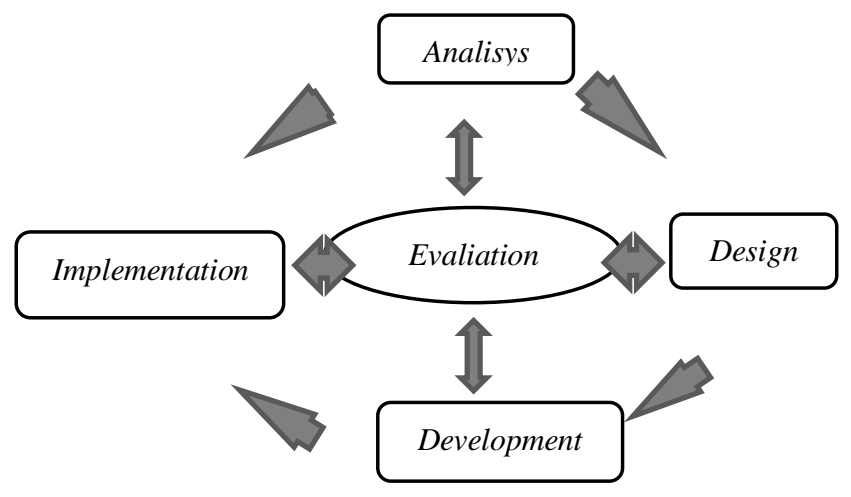

Gambar 1. Metode ADDIE

Adapun prosedur pengembangan model ADDIE sebagai berikut :

\section{Tahap Analysis (Analisis )}

Tahap analisis merupakan

proses analisis kebutuhan, mengidentifikasi apa yang akan dipelajari oleh peserta didik, maka langkah yang ditempuh pengembangan adalah penggalian informasi melalui pengamatan pengalaman peneliti saat melaksanakan PPL di kelas dua sekolah dasar. Sesuai dengan pengamatan yang dilaksanakan peneliti ditemukan saat pembelajaran bahasa Indonesia kususnya materi menyimak, guru hanya menggunakan media papan tulis, buku ajar, serta gambar-gambar yang diambil dari internet dan ditempel di papan tulis untuk dilihat bersama-sama dalam satu kelas.

\section{Tahap Design (Desain)}

Tahap desain/perencanaan terdiri dari kegiatan penyusunan kerangka struktur isi pembelajaran bahasa Indonesia kelas II dan menyusun desain perangkat media pembelajaran. Pada tahap penyusunan kerangka struktur isi pembelajaran bahasa Indonesia dikonsultasikan oleh ahli materi dan pada tahap penyusunan media akan dikonsultasikan oleh ahli media. Dalam langkah desain yang pertama dilakukan adalah merumuskan tujuan pembelajaran yang sesuai dengan materi dalam pembelajaran. Setelah selesai menyusun tujuan pembelajaran selanjutnya menyusun desain perangkat media, dan langkah -langkah nya sebagai berikut :

a. Menentukan jenis bahan perangkat media pembelajaran yang akan dipakai. Bahan yang akan digunakan pada media boneka tangan adalah kaos kaki, kain flannel, dan kardus bekas sebagai panggungnya.

b. Menentukan ukuran perangkat media pembelajaran boneka tangan. Ukuran kaos kaki dewasa, kain flannel sesuai ukuran yang diinginkan dan kardus bekas ukuran $34 \mathrm{~cm}$ x $26 \mathrm{~cm} \times 33 \mathrm{~cm}$.

c. Menentukan desain tampilan boneka tangan yaitu dapat ditampilkan seperti boneka sesuai dengan tokoh dalam cerita dan dilengkapi dengan panggung sebagai latar tempat kejadiannya dalam dongeng, sedangkan lubang pada kaos kaki digunkan untuk masuknya tangan saat mempraktekkan.

d. Menentukan warna yang akan digunakan pada media boneka tangan, yaitu menggunakan 
kaos kaki berwarna bebas, dan kain flannel warna-warni.

\section{Tahap Development \\ (Pengembangan)}

Tahap development disusun menjadi dua tahap untuk membuat sebuah media pembelajaran dari mainan boneka tangan, tahap tersebut meliputi:

a. T ahap Pembuatan Media

Pembelajaran Boneka Tangan

Pada tahap ini bahan yang

telah disiapkan akan di desain

atau di buat sesuai dengan

materi yang digunakan nantinya.

b. Tahap Validasi

Tahap validasi dilakukan oleh dosen ahli . Ahli media dilakukan oleh Yudha Popiyanto, S.Pd., M.Pd. sedangkan ahli materi dilakukan oleh dua orang ahli yaitu Rini Damayanti, S.Pd, M.Hum selaku dosen bahasa dan sastra Indonesia dan Dina Dwi Wahyuni P, S.Pd. selaku guru kelas 2. Hasil validasi berupa angket yang sudah dibuat oleh penulis.

\section{Tahap Implementasi}

Melihat adanya wabah COVID-19 tidak ada kemungkinan untuk mengimplementasikan media pembelajaran yang telah dibuat tidak dapat dilaksanakan disekolah, sehingga penelitian kali ini akan berhenti pada tahap validasi ahli media dan ahli materi.

\section{Tahap Evaluasi}

Pada tahap ini peneliti dapat melaksanakan evaluasi dari tahap validasi yang dilaksanakan oleh ahli media dan ahli materi, sebagai tolak ukur keberhasilan pembuatan media boneka tangan yang digunakan pada materi menyimak dongeng. Tahap analisis ini pula dipergunakan untuk mengukur kelayakan dan efektivitas media tersebut. Hasil evaluasi ini berupa angket validasi media dan materi.

\section{Jenis Data}

Data yang digunakan berupa kualitatif. Data kualitatif digunakan untuk mengukur tanggapan ahli media dan materi yang terangkum dalam butir-butir pertanyaan pada angket yang dibuat oleh peneliti sebagai tolak ukur kelayakan media dan materi.

\section{HASIL DAN PEMBAHASAN PENGEMBANGAN}

Pada dongeng kali ini penulis mengambil judul "Merpati Baik Hati”, sehingga boneka tangan dibentuk menjadi burung Beo dan burung Merpati, boneka tersebut terbuat dari kaos kaki dengan ukuran dewasa. Bagian sayap burung dibuat dari kain flannel dengan warna sesuai dengan tokoh. Untuk pembuatan panggung boneka tangan menggunakan 2 kardus air mineral ukuran $34 \mathrm{~cm}$ x $26 \mathrm{~cm}$ x $33 \mathrm{~cm}$ yang digabung menjadi satu sebagai latar tempat dongeng. Pada bagian kiri digunakan untuk latar hutan dan pada bagian kanan digunakan untuk latar rumah, kardus yang sudak disiapkan dibuang bagian atas kardus dan 
dilubangi berbentuk kotak mempentuk seperti pigura foto namun memiliki volume. Kardus tersebut dilapisi dengan kain flannel sesuai dengan ukuran dan warna yang diinginkan, untuk mempercantik panggung dilengkapi dengan hiasan sesuai latar tempat pada dongeng yang akan disampaikan.

Produk media boneka tangan yang telah dibuat harus melalui langkah validasi media yang dilakukan oleh ahlinya yakni bapak Yudha Popiyanto, S.Pd., M.Pd. dan validasi materi dilakukan oleh dua orang ahli materi yaitu Rini Damayanti, S.Pd, M.Hum dan Dina Dwi Wahyu P, S.Pd selaku guru kelas 2. Tahap validasi ini dilakukan untuk mengetahui kelayakan media yang diterapkan pada mata pelajaran bahasa Indonesia materi menyimak dongeng . Hasil validasi media memperoleh persentase sebesar 94\% menurut ahli media, produk yang dibuat menarik perhatian siswa dan layak digunakan untuk siswa kelas 2 . Pada hasil validasi materi dari validator pertama memperoleh persentase sebesar $88,3 \%$ dan persentase dari validator kedua sebesar $86,6 \%$ menurut ahli materi, materi yang dibuat sesuai dengan media boneka tangan, sehingga efektif dalam menarik perhatian siswa dan adanya peningkatan antusias belajar lebih tinggi. Sehingga dari persentase validasi dapat dikatakan bahwa media boneka tangan layak digunakan pada siswa kelas dua dengan materi menyimak dongeng.

Setelah melaksanakan tahap validasi maka tahap selanjutnya yaitu tahap uji coba yang akan dilakukan pada siswa Sekolah Dasar, namun mengingat keadaan yang tidak memungkinkan karena wabah COVID-19, maka penulis tidak melaksanakan uji coba pada siswa Sekolah Dasar, sehingga sebagai tolak ukur kelayakan penulis hanya sampai pada tahap validasi saja.

Berikut penyajian hasil validasi media pembelajaran boneka tangan dan materi yang telah dibuat oleh penulis pada lampiran halaman 12.

\section{SIMPULAN}

Media pembelajaran boneka tangan sangat tepat digunakan dalam pembeajaran bahasa Indonesia materi menyimak dongeng. Dengan pengembangan media boneka tangan ini penulis memberikan panggung boneka untuk menunjukkan latar tempat kejadian dongeng yang akan disampaikan dengan begitu pembelajaran akan lebih efektif dan menarik, serta dapat mengembangkan daya imajinasinya lebih tinggi. Untuk mengetahui kelayakan media tersebut penulis mengaplikasikan model pengembangan ADDIE (analysis, design, development, implementation, and evaluation) pada tahapan development mendapatkan kelayakan dari hasil validasi yang di lakukan penulis, Yudha Popiyanto, S.Pd., M.Pd 
sebagai validator ahli media dan dua validator ahli materi yaitu Rini Damayanti, S.Pd., M.Hum dan Dina Dwi Wahyu P, S.Pd. Hasil kelayakan media sebesar 94\%, sedangkan hasil kelayakan materi pada validator pertama sebesar $88,3 \%$ dan validator kedua sebesar $86 \%$. Maka dari hasil tersebut dapat disimpulkan bahwa media boneka tangan layak digunakan pada mata pelajaran bahasa Indonesia materi menyimak dongeng siswa kelas II Sekolah Dasar.

\section{Saran}

Adapun saran yang dapat penulis sampaikan yaitu:

a. Jika tidak adanya halangan seperti saat ini karena adanya wabah COVID-19, maka hasil kelayakan dapat dilakukan langsung pada siswa kelas II.

b. Media boneka tangan dapat menggunakan panggung dengan latar tempat yang lebih banyak lagi.

c. Guru dapat menggunakan media boneka tangan untuk menghidupkan suasana belajar siswa yang menyenangkan.

\section{DAFTAR RUJUKAN}

Ambiyara, N. J. (2016). Media Dan Sumber Pembelajaran. Jakarta: Kencana.

Andriani, R. (2017). Pengaruh Media Boneka Tangan Terhadap Kemampuan Menyimak Dongeng Siswa Kelas I SDN
Ponggok Kabupaten Kediri Tahun Ajaran 2016/2017. Simki-Pedagogia, 4.

Arsyad, A. (2013). Media Pembelajaran. Jakarta: PT RajaGrafindo Persada.

Cahyadi, R. A. (2019). Pengembangan Bahan Ajar Berbasis ADDIE Model. Education Journal, 35.

Chrisyarani, D. D. (2018). Pengembangan Media

Boneka Tangan dengan Metode Bercerita untuk Siswa Kelas V SDN Sudimoro 2 Kabupaten Malang. Jurnal Bidang Pendidikan Dasar (JBPD), 59.

Danim, S. (2008). Media Komunikasi Pendidikan. Jakarta: PT Bumi Aksara.

Desiningrum, N., Endang Nuryasana, dan Leni Yuliana. (2017). Teknologi Pembelajaran. Ponorogo: Uwais Inspirasi Indonesia.

Habsari, Z. (2017). Dongeng Sebagai Pembentuk Karakter Anak. Jurnal Kajian Perpustakaan Dan Informasi, 23.

Jalinus, N., \& Ambiyar. (2016). Media Dan Sumber Belajar. Jakarta: Kencana.

Nopriani, Y., Sri Saparahayuningsih , dan Yulidesni . (2016). Meningkatkan Keterampilan Menyimak Dengan Metode Bercerita Melalui Media Boneka Jari. Jurnal Ilmiah Potensia, 122.

Omih. (2017). Penerapan Metode Bercerita Dalam Upaya 
Meningkatkan Kemampuan

Menyimak Cerita Rakyat

Pada Siswa Kelas V SDN

Panyingkiran 3 Kabupaten

Semedang. Mpd, 63.

Susanto, A. (2013). Teori Belajar Dan Pembelajaran Di Sekolah Dasar. Jakarta: Prenadamedia Group.

Tegeh, I. M., \& I Made Kirna. (2013). Pengembangan Bahan Ajar Metode Penelitian Pendidikan Dengan Addie Model. Ejournal.Undiksa.Ac.Id, 16.

Trianto, A. (2007). Pasti Bisa Pembahasan Tuntas Kompetensi Bahasa Indonesia Untuk SMP Dan MTS Kelas VII. Esis.

Umam, N. K., Afakhrul Masub Bakhtiar, dan Hardian Iskandar. (2019). Pengembangan Pop Up Book Bahasa Indonesia Berbasis Budaya Slempitan. Trapsila: Jurnal Pendidikan Dasar, 3.

Widowati, D. A. (2016). Pengaruh Media Boneka Tangan Terhadap Keterampilan Menyimak Cerita Kelas II B SD Negeri Margoyasan. Jurnal Pendidikan Guru Sekolah Dasar, 2.583. 